\title{
PERBEDAAN EFEKTIFITAS EKSTRAK TEMULAWAK (Curcuma Xanthorrizae Roxb) DENGAN BERBAGAI KONSENTRASI TERHADAP PERTUMBUHAN CANDIDA ALBICANS PADA PLAT RESIN AKRILIK KURING PANAS - In Vitro
}

\author{
Inanda Nita *, Musri Amurwaningsih **, Uswatun N.A.Darjono **
}

\begin{tabular}{c}
\hline Keywords: \\
heat cured acrylic \\
resin, candida \\
albicans, curcuma \\
xanthorrizae roxb \\
extract
\end{tabular}

\section{ABSTRACT}

Background: Temulawak (curcuma xanthorrizae roxb) contains many substance such as xanthorrizol, curcumin, essential oil, flavonoid. Essential oil and flavonoid works by damaging the cell wall and protein denaturation can inhibits the growth of the fungi Candida albicans attached to the surface of the heat cured acrylic resin plate. The purpose of this study is to determine the extract Temulawak effect on the growth of Candida albicans at heat cured acrylic resin plate. Method : The Eksperiment is true experimental laboratories with post test only controlled group design. 10x10x2 mm Acrylic resin plate was soaked into Candida albicans suspension for 48 hours at $37^{\circ}$ then soaked in curcuma xanthorrizae roxb extract $90 \%, 80 \%, 70 \%$, $60 \%$, control group positive (chlorhexidine $0,2 \%$ ), control negatif (water) for 8 hours at $37^{\circ}$. Result: The result of the experiment showed that control group (-)has the highest value $(839,20 \times 101 \mathrm{CFU} / \mathrm{ml})$, while the least was $90 \%$ ekstract of curcuma xanthorrizae roxb group (23,40 x $101 \mathrm{CFU} / \mathrm{ml})$. After normality and homogenity test was done, One Way Anova test was executed $(p=0,000$. means $p<0,05)$. Conclussion: extract Temulawak can inhibit Candida albicans growth on heat cured acrylic resin.

\section{PENDAHULUAN}

Riset Kesehatan Dasar (RISKESDAS) Departemen Kesehatan Republik Indonesia tahun 2007 menyatakan bahwa prevalensi masalah gigi mulut bervariasi menurut karakteristik responden yaitu berkaitan dengan umur ${ }^{1}$. Semakin tinggi umur semakin meningkat pula prevalensi masalah gigi dan mulut, adanya koloni Candida albicans pada membran mukosa 55 orang pasien dari 105 orang pasien pemakai gigi tiruan penuh didapatkan prevalensi sebesar $51,4 \%{ }^{2}$. Keberadaan Candida albicans pada gigi tiruan merupakan faktor penyebab utama terjadinya denture stomatitis ${ }^{3}$. Pemakaian gigi tiruan lepasan menyebabkan sebagian dari mukosa mulutnya tertutup oleh basis gigi tiruan, sehingga dapat menganggu aliran saliva oleh karena gangguan kelenjar ludah dan mukosa. Adanya gangguan saliva mengakibatkan permukaan gigi tiruan terbentuk plak. Keberadaan ini memudahkan koloni antigen Candida albicans berkembang biak di tempat tersebut ${ }^{4}$. Pemakaian gigi tiruan yang terus-menerus dan tidak bersih dapat menimbulkan beberapa reaksi terhadap jaringan salah satunya denture stomatitis yang secara klinis dibagi menjadi tiga tipe yaitu 1). tampak hiperaemi berupa noda atau titik sebesar jarum pentul, 2). eritema yang tidak berbatas jelas, 3). inflamasi granuler atau radang hiperplasia papiler ${ }^{5}$.

WHO merekomendasikan penggunaan obat tradisional yang memiliki fungsi untuk pemeliharaan keseimbangan penyakit, pencegahan dan pengobatan penyakit, terutama penyakit kronis, penyakit degeneratif dan kanker. WHO

${ }^{*}$ Program Pendidikan Dokter Gigi UNISSULA, ${ }^{* *} F K G$ Universitas Islam Sultan Agung

Korespondesi: Inanda Nita (inanda.nita@gmail.com) 
juga mendukung upaya-upaya dalam peningkatan keamanan dan khasiat dari obat tradisional ${ }^{6}$. Salah satu obat tradisional komponen minyak atsiri dari rimpang Temulawak (Curcuma xanthorizae roxb) adalah xanthorrizol. Xanthorrizol ini memiliki kemampuan antibakterial, antiseptik, dan antibiotik ${ }^{7}$. Minyak atsiri yang dihasilkan dari rimpang temulawak juga dapat menghambat partumbuhan jamur Candida albicans ${ }^{8}$.

Penelitian ini bertujuan untuk mengetahui efektifitas ekstrak Temulawak (Curcuma xanthorizae roxb) terhadap pertumbuhan Candida albicans pada plat resin akrilik kuring panas secara in vitro. Hasil penelitian ini diharapkan dapat memberikan informasi ilmiah tentang khasiat esktrak Temulawak dan menetahui pengaruh ekstrak Temulawak terhadap pertumbuhan Candida albicans.

\section{METODE PENELITIAN}

Penelitian ini adalah penelitian eksperimental laboratoris yang dilakukan di Laboratorium Mikrobiologi Balai Laboratorium Kesehatan Semarang. Penelitian meliputi perhitungan jumlah koloni Candida albicans dan perhitungan KHM (Kadar Hambat Minimum).

Rimpang Temulawak yang digunakan adalah rimpang yang masih segar, tidak busuk, berwarna coklat gelap di bagian luarnya, dan bagian dalam berwarna kuning sebanyak $1,5 \mathrm{~kg}$. Ekstraksi dilakukan dengan metode maserasi. Rimpang Temulawak dicuci sampai bersih dan dihilangkan lapisan kulitnya,. Dikeringkan pada suhu $50^{\circ}$ selama 2 hari kemudian digiling hingga menjadi serbuk. Serbuk yang diperoleh ditimbang seberat 500 gr, dilakukan maserasi dengan menggunakan pelarut etanol $70 \%$ sebanyak $800 \mathrm{ml}$ selama 24 jam dengan suhu kamar normal yaitu $37^{\circ}$, kemudian dilakukan penyaringan dengan menggunakan corong buchner (Rianti, 2003). Filtrat hasil saringan diuapkan dengan menggunkan rotary evaporator, didapatkan ekstrak murni temulawak.
Setelah itu ekstrak yang diperoleh dituang di cawan porselin kemudian dipanaskan dengan water bath sambil terus diaduk. Proses ekstraksi selesai dan didapatkan ekstrak Temulawak dengan konsentrasi $100 \%$. Kemudian diencerkan dengan menggunakan akuades didapatkan konsentrasi $90 \%, 80 \%, 70 \%, 60 \%$.

Penelitian dilanjutkan dengan perhitungan jumlah koloni Candida albicans dengan cara sampel plat resin

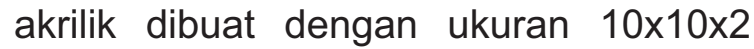
$\mathrm{mm}$ kemudian dilakukan sterilisasi plat tesin akrilik dengan menggunakan alat autoclave $121^{\circ}$ selama 18 menit. Plat resin akrilik direndam di dalam saliva steril selama 1 jam kemudian dibilas dengan menggunakan larutan PSB (Phosphate Buffer Saline) 2 kali. Plat resin akrilik dimasukkan kedalam tabung reaksi yang berisi suspensi Candida albicans yang sudah diinkubasi selama 24 jam kemudian di inkubasi lagi selama 24 jam pada suhu $37^{\circ}$. Selanjutnya plat resin akrilik yang sudah terpapar Candida albicans dimasukkan kedalam tabung reaksi yang berisi larutan ekstraksi Temulawak (Curcuma Xanthorizae Roxb) dengan konsentrasi $60 \%, 70 \%$, $80 \%, 90 \%$, kontrol positif (chlorhexidine $0,2 \%$ ), dan kontrol negatif (air akuades) selama 1 jam. Kemudian plat resin akrilik kuring panas dimasukkan ke dalam Saboraud broth $10 \mathrm{ml}$, dan di vibrasi dengan menggunakan vortex mixer selama 1 menit untuk menghilangkan Candida albicans yang melekat pada plat resin akrilik kuring panas. Selanjutnya dilakukan pengenceran seri sampai 101 - Diambil 0,1 ml dalam Saboraud broth kemudian diteteskan pada petri agar Saboraud dextrose agar. Chlorhexidine $0,2 \%$ sebagai control $(+)$ dan akuades sebagai kontrol (-) selanjutnya di inkubasi selama 48 jam pada suhu 370 . Selanjutnya dilakukan perhitungan jumlah koloni Candida alicans dan KHM (Kadar Hambat Minimum)

Analisis data data dilakukan setelah diperoleh data dari 4 kali pengulangan. Dilakukan uji normalitas dan homogenitas. 
Sebaran data yang diperoleh normal dilanjutkan dengan uji parametrik One way Anova dan Post Hoc.

\section{HASIL PENELITIAN}

Hasil perhitungan jumlah koloni Candida albicans dilakukan dengan cara menghitung jumlah koloni Candida albicans yang tumbuh pada media Sabouraund's dextrose agar.

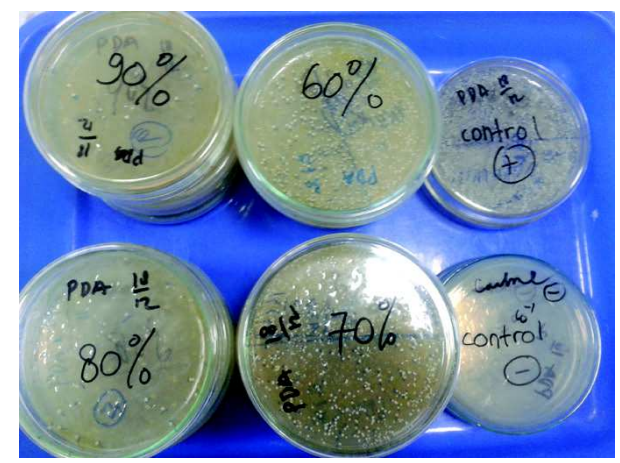

Gambar 1. Perhitungan jumlah koloni Candida albicans pada media Sabouraund's dextrose agar

\begin{tabular}{ccccccc}
\hline Konsentrasi & \multicolumn{3}{c}{$\begin{array}{c}\text { Jumlah Koloni } \\
\text { Candida albicans per } \\
\end{array}$} & \multicolumn{5}{c}{ SDA } & $\begin{array}{l}\text { Mean } \\
\text { per } \\
\text { SDA }\end{array}$ & SD \\
\cline { 2 - 5 } & I & II & III & IV & & \\
\hline $90 \%$ & 16 & 37 & 16 & 23 & 23,00 & 9,89 \\
$80 \%$ & 27 & 32 & 35 & 26 & 30,00 & 4,24 \\
$70 \%$ & 434 & 341 & 396 & 428 & 399,75 & 42,57 \\
$60 \%$ & 445 & 460 & 438 & 407 & 437,5 & 22,3 \\
Kontrol (+) & 20 & 56 & 43 & 78 & 49,25 & 2,426 \\
Kontrol (-) & 841 & 827 & 811 & 842 & 830,20 & 14,54 \\
\hline
\end{tabular}

Tabel 1. Hasil Penghitungan Jumlah dan Angka Koloni Candida albicans pada media Sabouraund's dextrose agar dengan konsentrasi $90 \%, 80 \%, 70 \%, 60 \%$, kontrol positif (chlorhexidine $0,2 \%$ ), dan kontrol negatif (air akuades) (x $101 \mathrm{CFU} / \mathrm{ml}$ )

Hasil penelitian menunjukan total ratarata jumlah koloni Candida albicans pada media Sabouraund's dextrose agar yang sudah dilakukan 4 kali pengulangan, didapatkan nilai tertinggi pada kelompok kontrol negatif (air akuades) dengan jumlah koloni Candida albicans sebanyak $830,20 \times 101 \mathrm{CFU} / \mathrm{ml}$ dan rerata total terendah pada esktrak Temulawak konsentrasi $90 \%$ sebanyak $23,00 \times 101$ $\mathrm{CFU} / \mathrm{ml}$.

\section{PEMBAHASAN}

Hasil penelitian menunjukan bahwa efektifitas ekstrak Temulawak dalam menghambat Candida albicans pada plat resin akrilik kuring panas sudah terbentuk, yaitu pada konsentrasi $90 \%$. Seiring dengan peningkatan konsentrasi. Hal ini sesuai dengan pendapat Pelszar dan Chan, adalah semakin tinggi konsentrasi suatu bahan ekstrak maka semakin efektif pula meikroorganisme akan terbunuh semakin banyak ${ }^{9}$.

Perhitungan KHM dengan menggunakan jumlah dan angka jamur Candida albicans kelompok kontrol sebesar 859,20 x 101CFU/ml dan jumlah jamur Candida albicans pada masingmasing konsentrasi didapatkan KHM pada ekstrak Temulawak konsentrasi $90 \%$ sebesar $97,385 \%$, konsentrasi $80 \%$ sebesar $96,59 \%$, konsentrasi $70 \%$ sebesar $54,55 \%$, konsentrasi $60 \%$ sebesar $50,26 \%$. Berdasarkan perhitungan KHM ini diketahui bahwa konsentrasi tersebut bersifat fungistatik.

Ekstrak Temulawak memiliki efektifitas dalam menghambat pertumbuhan Candida albicans pada plat resin akrilik kuring panas. Ini sesuai dengan pendapat Rukayadi dan raharjo bahwa kandungan Temulawak yaitu xanthorizol dapat menghambat kinerja antifungal Candidiasis albicans, Candidiasis glabarata, Candidiasis guilliermondii, Candidiasis krusei, Candidiasis parapsilosis, Candidiasis tropicalis ${ }^{10,8}$.

Rimpang temulawak mengandung bahan aktif yakni minyak atsiri sebagai antiseptik, antioxidan, antifungi, dan juga dapat membunuh bakteri gram positif dan gram negatif dan flavonoid. Minyak atisiri dari temulawak terdapat kandungan xanthorizzol (memiliki kemampuan antibakterial, antiseptik, dan antibiotik), germakren, tricyclin, dan isofurogermaken, kurkumoid ${ }^{7,11,12}$. Minyak 
atsiri dapat menghambat pertumbuhan dan mematikan kuman dengan cara menghambat proses terbentuknya dinding sel, sehingga dinding sel apabila terganggu maka akan tidak terbentuk secara sempurna sehingga dapat mengakibatkan sel jamur menjadi mati ${ }^{13}$. Flavonoid merupakan salah satu senyawa dari ekstrak temulawak yang memiliki aktifitas biologis yang luas termasuk sebagai antivirus dan antimikroba. Mekanisme kerja dari flavonoid dengan cara membunuh jamur dengan cara denaturasi protein sehingga dapat meningkatkan permeabilitas sel ${ }^{14,15}$.

Hasil penelitian ini hampir sama dengen penelitian Putri, bahwa semakin tinggi konsentrasi infusa temu putih maka semakin banyak bahan aktif seperti minyak atsiri dan flavonoid yang terkandung di dalam infusa temu putih sehingga dapat menghambat pertumbuhan jamur Candida albicans juga semakin besar, ini didapatkan pada konsentrasi $100 \%{ }^{16}$.

Hasil uji One Way Anova didapatkan nilai $p=0,000(p<0,05)$ yang menunjukan bahwa adanya perbedaan yang signifikan dari konsentrasi $90 \%, 80 \%, 70 \%, 60 \%$, kontrol positif (chlorhexidine 0,2\%), dan kontrol negatif (air akuades) dan hasil uji Post Hoc menunjukan bahwa adanya perbedaan yang signifikan kecuali pada konsentrasi $90 \%$ terhadap konsentrasi $80 \%$ dan kelompok kontrol $(+)$, konsentrasi $80 \%$ terhadap kontrol $(+)$, yang menunjukkan adanya perbedaan yang tidak siginifikan. Hal ini dikarenakan adanya selisih yang tidak terlalu jauh antar kelompok kontrol (+), kontrol (-) dan juga ke empat konsentrasi yang diuji.

Dapat ditarik kesimpulan dari penelitian ini yaitu adanya perbedaan jumlah jamur dan KHM yang dihasilkan oleh ekstrak temulawak konsentrasi $90 \%$, $80 \%, 70 \%, 60 \%$, menunjukan bahwa ekstrak temulawak konsentrasi $60 \%$ merupakan konsentrasi paling minimum dalam menghambat Candida albicans yaitu dengan presentase $50,26 \%$, hal ini dikarenakan semakin tinggi konsentrasi ekstrak temulawak semakin banyak pula kandungan minyak atsiri dan flavonoid yang bertindak sebagai antifungal, antibakterial, antioksidan yang terkandung di dalamnya

\section{KESIMPULAN}

Dari hasil penelitian dapat disimpulkan bahwa Terdapat perbedaan efektifitas ekstrak Temulawak konsentrasi $90 \%, 80 \%, 70 \%, 60 \%$, kelompok kontrol (+) dan kelompok kontrol (-) terhadap pertumbuhan jumlah koloni Candida albicans pada plat resin akrilik kuring panas. Ektrak temulawak konsentrasi 90\% merupakan konsentrasi paling efektif dalam menghambat Candida albicans pada plat resin akrilik kuring panas, ini dikarenakan semakin tinggi konsentrasi ekstrak semakin efektif pula mikroorganisme akan mati.

\section{DAFTAR PUSTAKA}

1. Badan Penelitian dan Pengembangan Kesehatan, (2007), Laporan Nasional Riset Kesehatan Dasar (RISKESDAS), Jakarta: Departemen Kesehatan Republik Indonesia, 2008: $132-5$

2. Monroy TB, Maldonado VM, Martinez FF., (2005), Candida albicans, Staphylococcus aureus and Streptococcus mutans colonization in patients wearing dental prosthesis, Medical Oral Patology Cir Bucal; 10,h.27-39

3. Waters M.G.J, Williams D.w., Jagger R.G., Lewis M.A.O., 1997, Adherence of Candida albicans to Eksperimental Denture Soft Lining Material, Journal Prosthetic Dentistry ; 77(3), p : 306-312

4. Soenartyo H., (2000), Denture stomatitis: penyebab dan pengelolaannya. Majalah Kedokteran Gigi, 33 (4): 148-151

5. Malcolm A.L., (2001), Red and White Lesions of The Oral Mucosa, Burkets Oral MedicineDiagnosis and Treatment (9th ed), Lippincot Raven publishers: $51-120$

6. WHO, (2003), Traditional medicine. Diakses Januari 2006 dari http://www.who.int/ mediacentre/factsheets/fs134/en/

7. Nur, S.W., (2006), Perbandingan Sistem Ekstraksidan Validasi Penentuan Xanthorrhizol dari Temulawak secara Kromatografi Cair Kinerja Tinggi, Skripsi, Bogor : Falkutas Matematika dan IImu Pengetahuan Alam, Institut Pertanian Bogor

8. Rahardjo, M., (2010), Penerapan SOP 
Budidaya Untuk Mendukung Temulawak Sebagai Bahan Baku Obat Potensial, Desember, 9(2): 78-93

9. Pelczar dan Chan, 1988. Dasar-Dasar Mikrobiologi Jilid 2, Jakarta: Universitas Indonesia.

10. Rukayadi Y., Yong D., Hwang J.K., (2006), In vitro Anticandidal Activity of Xanthorrhizol Isolated from Curcuma xanthorrizha Roxb, 57: 1231-1234

11. Sidik, Mulyono M. W., Mutasi A., (1995). Temualawak (Curcuma Xantrhorizae Roxb), Jakarta : Phytomedika

12. Hanoem E.H., Imam B, Parnoto K.P., (2011), The effectiveness of Nigela sativa seed extract in inhibiting Candida albicans on heat cured acrylic resin, Surabaya : Dental Journal, 44(3): $137-140$

13. Ajizah A, (2004), Sensitifitas Salmonella Typhiurium terhadap Ekstrak Daun Psodium
Guajava L, Bioscientiae, 1: 31-8

14. Wahyuningtyas, E., 2008, Pengaruh Ekstrak Graptophyllum Pictm Terhadap Pertumbuhan Candida albicans Pada Plat Gigi Tiruan Resin Akrilik, Indonesian journal of dentistry: 15(3): 187-191

15. Jawetz M, Aderberg's., (2007), Medical Microbiology (24th ed), US America : Mc Graww Hill Medical, h. 642

16. Putri D.E., Hendrijantini Nike, Sukaedi., (2011), Efektifitas Infusa Rimpang Temu Putih sebagai Desinfektan pada Resin Akrilik terhadap Candida albicans (analitik eksperimental laboratoris), Surabaya : Journal of Prosthodontics. 2(1): 20-24 